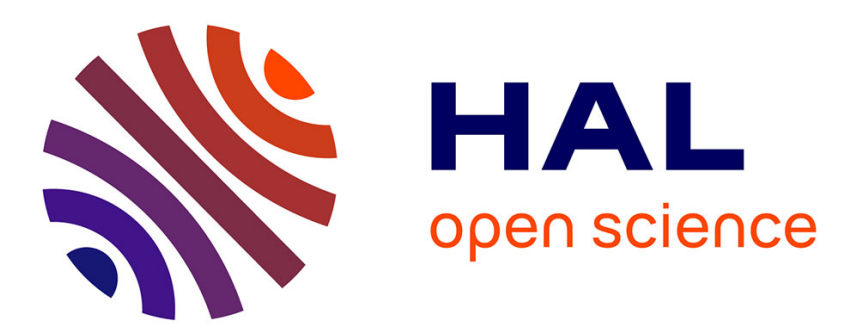

\title{
Evaluation of the quality and quantity of compost and leachate from household waterless toilets in France
}

Behzad Nasri, Florent Brun, Olivier Fouché

\section{To cite this version:}

Behzad Nasri, Florent Brun, Olivier Fouché. Evaluation of the quality and quantity of compost and leachate from household waterless toilets in France. Environmental Science and Pollution Research, 2018, 26 (3), pp.2062-2078. 10.1007/s11356-017-0604-z . hal-01811052

\section{HAL Id: hal-01811052 \\ https://hal.science/hal-01811052}

Submitted on 8 Jun 2018

HAL is a multi-disciplinary open access archive for the deposit and dissemination of scientific research documents, whether they are published or not. The documents may come from teaching and research institutions in France or abroad, or from public or private research centers.
L'archive ouverte pluridisciplinaire $\mathbf{H A L}$, est destinée au dépôt et à la diffusion de documents scientifiques de niveau recherche, publiés ou non, émanant des établissements d'enseignement et de recherche français ou étrangers, des laboratoires publics ou privés. 


\title{
Evaluation of the quality and quantity of compost and leachate from household waterless toilets in France
}

\author{
Behzad Nasri ${ }^{1} \&$ Florent Brun ${ }^{2} \&$ Olivier Fouché ${ }^{3}$
}

\begin{abstract}
One of the most undesired wastes is the human excreta due to the socio-environmental pressure. Otherwise, the nutriments contained in human excreta could be used as fertilizers to enrich the soil. Familial waterless litter composting toilets (FWLCT) are an alternative for locations where a centralized sewerage network cannot be provided or where there is a lack of standard urban infrastructure including roads, electricity, and water supply. The scientific researches on the composting techniques, the methods of control of the composting processors, and the rate of produced leachate are very limited. In this research, the composting systems included a feces and urine collection device. In each passage, the litter (carbonaceous material) is added to the excreta. Regularly, the buckets were emptied into a composting device located outside the house to which an additional portion of carbonaceous materials can be added. Monitoring was carried out on five rural and one urban familial composting areas in France for 1.5 years. The physiochemical and microbiological properties of the compost and leachate have been monitored and measured in compliance with the protocols. The results show that one of the main problems of this system of human excreta treatment is that the composting process does not achieve a significant rise in temperature and does not allow reaching the optimum temperatures $\left(>50^{\circ} \mathrm{C}\right)$. Otherwise, from an agronomic point of view, the obtained compost is not rich enough in nutriments to be a good compost as soil fertilizer. But it can be used as a soil conditioner. The average leachate flux from the composters is $1.79 \mathrm{~L} /$ day. Because of the very short stay time in the piles, the leachate is contaminated by harmful bacteria and should be treated by another sanitation system.
\end{abstract}

\section{Keywords}

Composting toilets. Human excreta treatment and management. Environmental discharge. Chemical flux

\section{Introduction}

Elimination of human excreta is one of the first priorities of mankind merely because of its olfactory annoyance. Later, many other reasons took part as motivation to treat (before elimination) the excreta, such as prevention of diseases in the society (Bartram and Cairncross 2010; Prüss-Ustün et al. 2014), protection of soil and water resources, and reduction of environmental impacts (Baum et al. 2013). According to data from the World Health Organization, one billion people still practice open defecation around the world, which can provoke all the abovementioned threats. For this reason, providing basic sanitation is one of the United Nation's Millennium Development priorities (WHO/UNICEF 2014). In many parts of the world (essentially in poor countries), providing centralized sewerage networks and wastewater treatment plants (WTP) is not possible, because of several indecorous problems, such as global unfair wealth distribution, climatic and hydrological constrains (such as water scarcity, topography), and demographic habits. These areas suffer from the lack of standard urban infrastructure including roads, electricity, and water supply. In the absence of this equipping, human excreta treatment efficiency becomes susceptible and offensive but is essential to prevent environmental impacts and disease transmission (Hill and Susan 2012).

To compensate these lacks, proposing a system with minimalmaintenance effort and cost is needed to treat human excreta. Therefore, on-site sanitation (OSS) systems (Strande et al.2014) are often the most appropriate solution (Paterson et al.2007). The OSS can be divided in two global classes: wet OSS(using water to treat) and waterless OSS. Concerning the wet OSS, two questions come up for the major types of OSS. Firstly, the permitting,

\footnotetext{
${ }^{1}$ Behzad Nasri behzad.nasri@lecnam.net, GeF lab., Geomatique \& Foncier, EA 4630, Le Cnam, 2 rue Conté, 75003 Paris, France

2 Toilettes Du Monde, 28 place du docteur Bourdongle, 26110 Nyons, France

${ }^{3}$ Behzad Nasri behzad.nasri@lecnam.net, GeF lab., Geomatique \& Foncier, EA 4630, Le Cnam, 2 rue Conté, 75003 Paris, France
} 
construction, function, and maintenance of onsite systems in these zones can be challenging where shallow soils, steep terrain, limited vegetation, and short seasons exist and cause the dysfunction of the system (Weissenbacher et al. 2008). Secondly, once the OSS are installed, the leaching of high load of human excreta is concentrated directly into the subsurface. Consequently, the dysfunction of the OSS can transfer a significant amount of contaminant downwards and deteriorate the quality of local drinking water sources, lakes, streams, and groundwater (Dzwairo et al. 2006; Pujari et al. 2007; Withers et al. 2012; Templeton et al. 2015). Another disadvantage of wet systems mainly stems from the mobility given to the toilet waste by water. Water might conveniently remove the waste from the toilet room, but it is then difficult to contain and can easily spread both nutrients and pathogens to pollute valuable water supplies. It also means that often scarce potable water is wasted in that process (Bencke GA, The ecology and conservation of the bluebellied parrot Triclaria malachitacea in forest fragments in Rio Grande do Sul, Brazil. Final report to Universidade Estadual Paulista_UNESP, Unpublished work).

Waterless toilets (Del Porto and Steinfeld 1998; Rubin et al. 2012) are an alternative solution which has been primarily used in rural areas and areas with water shortages or environmental sensitivity (Chapman 1993; Depledge 1997; Fittschen and Niemczynowicz 1997; Cordova and Knuth 2005; Kaczala 2006; Tønner-Klank 2007). In waterless composting toilets (WCT), excreta fall into a watertight tank to which ash or vegetable matter is added (Franceys 1992). If suitable conditions (moisture content, temperature and chemical balance, carbon to nitrogen ratio, $\mathrm{pH}$, particle size, porosity, oxygen concentration) are provided, the mixture will decompose, by aerobic reactions (Rapaport 1996), to form a good soil conditioner in some months. The produced compost has a good fertilizer value and can be applied on agricultural land (Dharmabalan 1988) or can be safely disposed of in the environment after adequate time has passed for composting. This compost is also called humus, which is a harmless residual of human excrement.

As WCT require little to no water, they can therefore disconnect the toilet from both the water supply and wastewater infrastructure. Another advantage of composting toilets is its nutrient cycling and transportation. Similar to solids obtained from traditional wastewater treatment plant, the solids obtained from composting toilets can also be used as a fertilizer; yet, they would be free from the urban runoff contamination and may require less transportation if they can be applied where compost is produced (Anand and Apul 2014).

On the other hand, the WCT need a careful operation and maintenance. Ash or vegetable matter (litter) must be regularly added. Compost could be a health hazard if it is removed before decomposition is complete. If it is necessary to construct the toilet collection chamber (pile) above ground for good ventilation and easy access to remove compost, the structure may be considered unsightly and obtrusive. Access, via steps or a ramp, can be a problem for the elderly or disabled. Insect breeding in the chamber can become a problem if the toilet lid is not kept down and other ventilation and access openings are inadequately sealed against insects. (Depledge 1997).

More common problems which WCT might encounter are the following: low temperature, anaerobic condition, moisture content, and leachate accumulation in the composting pile.

Temperature monitoring is attractive as a potential stability- maturity evaluation method because it is simple, fast, and inexpensive (Boulter-Bitzer et al. 2006; Weppen 2001) and because pile temperatures are a routine part of most compost monitoring programs. Different phases of composting are indicated by differing temperatures (Anand and Apul 2014). Composting begins when the readily degradable organic matter is degraded by mesophilic organisms that function at a temperature range of $19-45{ }^{\circ} \mathrm{C}$ (Depledge 1997). The produced heat during this process causes the rise of the compost temperature to above $45{ }^{\circ} \mathrm{C}$ where thermophilic organisms become active (Jenkins 1999; Zavala and Funamizu 2006). The rate of compost biodegradation is faster in thermophilic phase than that in mesophilic phase (Zavala et al. 2004). Maximum degradation of organic matter and destruction of pathogens occur during the thermophilic phase at a temperature range of about $50-65{ }^{\circ} \mathrm{C}$ (Bernal et al. 2009; Nataka et al. 2003). An early study reported the optimum temperature range for composting equal to $40-65{ }^{\circ} \mathrm{C}$ (de Bertoldi et al. 1983). A more recent study suggested $60{ }^{\circ} \mathrm{C}$ as the optimum temperature for feces degradation (Zavala and Funamizu 2006). At temperatures over $65^{\circ} \mathrm{C}$, the compost activity reduces, as most thermophilic organisms cannot survive at this temperature (Germer et al. 2010). But, generally, continuous addition compost toilets have pile temperatures ranging between 20 and $35^{\circ} \mathrm{C}$ (Smith 1981), although, some lower values were recorded by Enferadi (1981). Often, when compost toilets do not perform satisfactorily, cold ambient temperatures are blamed. Thermophilic temperatures are seldom attained, if ever they are essential to have a reliable mechanism of pathogen destruction (Redlinger et al. 2001; Holmqvist and Stenstrom 2002; Jenkins 2005; Tønner-Klank 2007; Jensen et al. 2009). 
Aerobic condition is necessary for composting. As anaerobic conditions produce very little heat and most of the energy in the organic matter is in the methane it produces, it results in low pile temperatures. Also, foul smells because of produced sulfur (Chapman 1993). In addition, the higher the moisture is, the less space is available for air. Miller (1992) suggest that the optimum oxygen concentration should range between 15 and $20 \%$. Lack of oxygen in the pile can cause anaerobic conditions which lead to odor issues and reduce the rate of composting. On the other hand, excess airflow is not recommended either since it can remove too much heat and water vapor from the compost.

Generally, the airflow through the toilet evaporates liquid from the pile, and any excess is drained away as required. However, liquid accumulation is often considered as a problem in the literature on composting toilets (Chapman 1993). According to Kaczala (2006), various composting toilet designs, such as inclined surfaces, evaporation in electrical toilets, and solar toilets, have been proposed and commercialized to solve the leachate accumulation problem. In addition, Abbott (2004) proposed evapotranspiration beds for excess leachate. Winblad et al. (2004) discussed several techniques of composting toilets including the technics to prevent leachate accumulation. In contrary, there are environmental risks associated with the operation of a WCT which have a continuous discharge of leachate. Despite effort to provide drainage, saturation causes anaerobic conditions which disturb the composting process (Hill and Susan 2012). However, moisture in compost is necessary for adequate microbial activity since the aqueous medium makes the nutrients physically and chemically accessible to microorganisms. Many studies show that the optimum moisture content for proper composting is 50-60\% (Zavala and Funamizu 2006; Jenkins 1999; Gajalakshmi and Abbasi 2008).

However, to be considered beneficial, a compost must be of high quality. It must be safe for human, plants, and the environment, and beneficial for the soil health. In other words, it should be free from pathogenic organisms, contain only minimal amounts of foreign materials, have acceptable levels of trace elements and organic contaminants, and be sufficiently mature and stable (Wichuk and McCartney 2010).

Another safety consideration concerning the use of compost as soil amendment or as fertilizer is its pathogen content. Compost can contain many types of pathogenic bacteria, viruses, protozoa, helminth, and fungi that can cause various diseases. During composting, these pathogens are reduced by several processes including thermal destruction, competition between indigenous microorganisms and pathogens, antagonistic relationships between organisms, the action of antibiotics produced by certain fungi, natural die-off in the compost environment, production of toxic by-products such as gaseous ammonia, and nutrient depletion (Wichuk and McCartney 2010). For human safety, the product issued a composting toilet should not have more than 200 most probable number (MNP) per gram of fecal coli form bacteria (Del Porto and Steinfeld 1998).

Some researches assessed the performance of compost toilets (Stoner 1977; Smith 1981; Enferadi 1981; Smith et al. 1984; Young 1986). Most of the reports have identified low composting temperatures, anaerobic conditions, and excess liquid buildup as the main problems. Smith (1981) compiled a report on the performance of 33 compost toilets in National Forests in the USA and noted that most toilets were aerobic in the top section and anaerobic in the lower section. He carried out the microbial analysis which showed that neither bin nor continuous composting reduced fecal coli forms to acceptable levels and found, from ash and chemical oxidation demand (COD) analysis, that composting was not complete.

Familial composting of human excreta is one of the feasible practices which can be managed by the household. Two reports assessed the performance of familial compost toilets in private households. In the first one, Leich (1981) in a research for Norwegian assessment of compost toilets found that large box toilets were mostly unsatisfactory, while the performance of other sizes varied from good to bad. The second report was prepared by the California Department of Health and found generally mediocre performance, especially in terms of fecal indicator species (Enferadi 1981).

The composting process is well understood, thanks to large scale composting, but the applicability of the research to small-scale compost toilets is uncertain (Chapman 1993). Despite the benefits, the lack of knowledge and awareness of composting toilets remains a barrier to their acceptance and implementation. Starting in 1970s, as wastewater treatment research received much attention and saw major developments, the topic of composting toilets has been neglected by the sanitation community including researchers and professionals (Anand and Apul 2014). All these impose the necessity to evaluate the status of composting toilets and bring awareness to this technology so they can be better evaluated for possible adoption as an alternative sustainable sanitation system. 
Our study characterizes the compost and leachate composition and flux from familial waterless litter composting toilets (FWLCT) in dispersed rural areas in France (except one site which is in urban area) and evaluates its threat to the environment. It tries to note its value as a fertilizer for the household scale uses. We examined the basic nutriment as phosphorus and nitrogen, the pathogenic parameters, and the leachate flux to estimate the flux rate to the environment.

\section{Material and method}

This study concerns familial waterless litter composting toilets(FWLCT) which is the most employed system in France. According to the French Ecological Sanitation Network (Réseau d'Assainissement Ecologique, RAE), with the collaboration of French Public Service of On-Site Sanitation (Service Public d'Assainissement Non Collectif, SPANC), in 2014, approximately $5 \%$ of the installations of on-site sanitation (OSS) were equipped with FWLCT. They consider this system as an ecological alternative to flush toilets.

This system involves discontinuous composting. It means, initially, the collection of feces and urine is carried out in the same sealed receptacle. The addition of the litter (carbonaceous material), after each passage, allows to partially absorb the leachates (urine that has been in contact with feces); also, the litter covers the excreta to regulate the odors and allows the aeration of the mixed material. The presence of urine could facilitate the composting process, by means of supplying nitrogen and moisture. Then, the bucket must be emptied into a composting device located outside the house (on the parcel of the house) to which an additional portion of carbonaceous materials (litter) can be added.

The literature and the French legislation concerning the quality of the obtained compost and the liquid discharges, resulting from this type of composting, remain very limited. So, it is pertinent to carry out a scientific follow-up of the byproducts of the FWLCT. It is because of its representativeness in France but also because it requires handling interventions y users. This participation in handling could generate possible risks, particularly, regarding the composting process that is specific to this type of waterless toilet.

In French technical legislations, it is nevertheless recommended to install watertight composting areas or to collect the leachates in a cask without further knowledge of the volume and composition of the compost. Then, in 2013, PANANC (French National Program on OSS) recommended a guide for SPANC which specifies that the waterproof area is only necessary in areas with health or environmental issues. But, there is no clear definition of areas with health or environmental issues. In this study, the compost and leachate from the FWLCT are targeted.

\section{Implementation of scientific protocol}

The protocol concerns the treatment of sub-products of FWLCT by composting and also concerns the leachate characterization. According to an accurate planning, the samples were collected, and physio-chemical and microbiological properties were measured for both, the compost and the leachate.

The duration of composting and monitoring on six familial composting areas is 1.5 years. This time corresponds to the beginning of the filling phase of the first tank up to 1 year of composting ( 6 months of filling of the first tank +1 year of composting).

For the leachate, the monitoring of four composting areas during the 6 months of filling of the first tank (most sensitive period to produce leachates) was defined. The total duration of the study is therefore 2 years (of which 1.5 of follow-up): from June 2012 to June 2014.

\section{Study sites}

For this study, six households, as pilot sites, have been chosen all over France (five sites in rural areas and one site in urban area). Household selection was important as they were asked to follow a management protocol throughout the study and to participate in the data acquisition. It was possible to find families motivated by the project, notably through members of the RAE who have already a management habit close to the chosen protocols. Thus, six households were selected to be followed. They use FWLCT and carry out composting in three enclosed weatherprotected areas. For the reason of homogeneity, they were asked to maintain a regularly manner of using the toilets. This was to limit the risks of non-compliance with the instructions. A detailed characterization was necessary in order to be efficient in the interpretation of the results. 
Two sites are in the south of France (Nyons and Gigondas) in a dry Mediterranean climate although the site of Nyons (urban area) is in North side, under trees. The other four sites are located in Brittany (Kergrist Moelou, Landévant, Plédran, and St. Barthélémy) in a rural temperate ocean climate.

\section{Composters (compost piles)}

The studied composters are self-constructed with manufactured products to represent the diversity of devices that can be found in France to build the composters. They are of a minimum volume of $1 \mathrm{~m} 3$, closed by a removable watertight roof, to limit the access to the pests (mammals, etc.) and to limit the drying up of the compost, to protect them from bad weather (rain, wind, sun). Two types of composter have been installed. The bottom-free composters, for their part, are the composters placed on the soil, thus allowing leachate infiltration into the soil (Fig. 1). Some of them are equipped with drains to prevent the ingress of runoff. In addition, four watertight composters have a watertight bottom that allows the leachate to be collected in a sealed container (Fig. 2).

\section{Litter and management practices}

The type of employed litter is usually a mixture of sawdust and woodchips, which is in accordance with the most common waterless toilets. Mixing with kitchen waste and green waste is not permitted. Although these additions are relatively widespread to diversify inputs and facilitate composting, but, to avoid analytical biases, such additions were forbidden (because of dilution, difficulty in correctly characterizing them, etc.).

To study the impact of certain variables on the composting and hygienist process, the six followed installations are divided into two groups of three devices with distinct characteristics. The chosen variable is the type of management by the users. Practically, the composting of dry toilet by-products can range from minimal management, which means simple storage of successive emptying in composters (minimum), to more elaborate modalities, mixing of the surface layer during drainage, watering according to the observed moisture content, and complete turning of the composting tank content during the composting process, etc. (optimized). This improved management procedure would make composting more active and therefore possibly faster. Jenkins (1999) confirms that optimized compost management can achieve thermophilic degradation at temperatures high enough to sanitize human excreta. However, no data of this research can confirm that it also provides a more hygienic treatment. The study protocol has therefore selected three composting areas with «minimum » management and three composting areas with « optimized » management (Table 1).

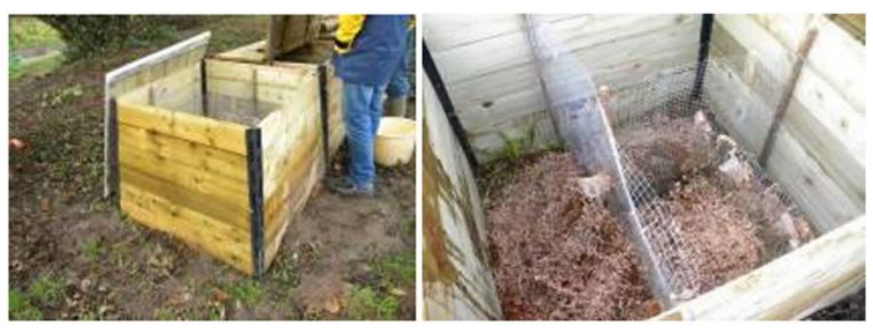

Fig. 1 Composter with free bottom on the local soil

The minimum management points the conditions of management of composter with a basic and accessible user service. It means that emptying is done by pouring the container (bucket) content on the top of the composting matters. After emptying, the container is rinsed with clear water and a brush, and this water is returned in the composter. The evacuated matter could be covered (without any obligation) by a layer of litter (rectification of moisture is not permitted). For the composters with the minimum management, the fourth method for sampling, it causes an unintended mixing of matters.

The optimized management points the condition of management which permits an optimized composting process. By this method, the emptying is done by mixing the first centimeters of the compost surface with the added matters (litter) (Fig. 3). In this stage, it is necessary to check the moisture content of the compost. Container rinsing is done similarly to the minimum management method. Adding the litter, to cover the top of the compost tank, is done, depending on the compost state and encourages aeration. Composter filling is done in a uniform way on the entire surface, and watering to increase the moisture content is allowed.

\section{In situ measuring of physio-chemical parameters}


The frequent punctual (by one person) or continuous (by permanent probes) measurements were done for the following parameters.

\section{Input rate of urine and feces}

By providing the info-sheet for each household, they were asked to fill the tables (adult/child, urine, urine + feces) at each passing to FWLCT.

The mass of urine and feces input in the composters was estimated, thanks to the data collected by each household.

During 6 months of the composter filling phase, at each emptying of the FWLCT, the mass of the discharged matter into the composter was weighted. The mass of percolated leachate across the compost was collected in a big graduated bottle and measured between each emptying with a balance. The mass of the carbonated litter which was put directly in the composter, at each emptying, and the litter that service user put in the FWLCT, have been evaluated.

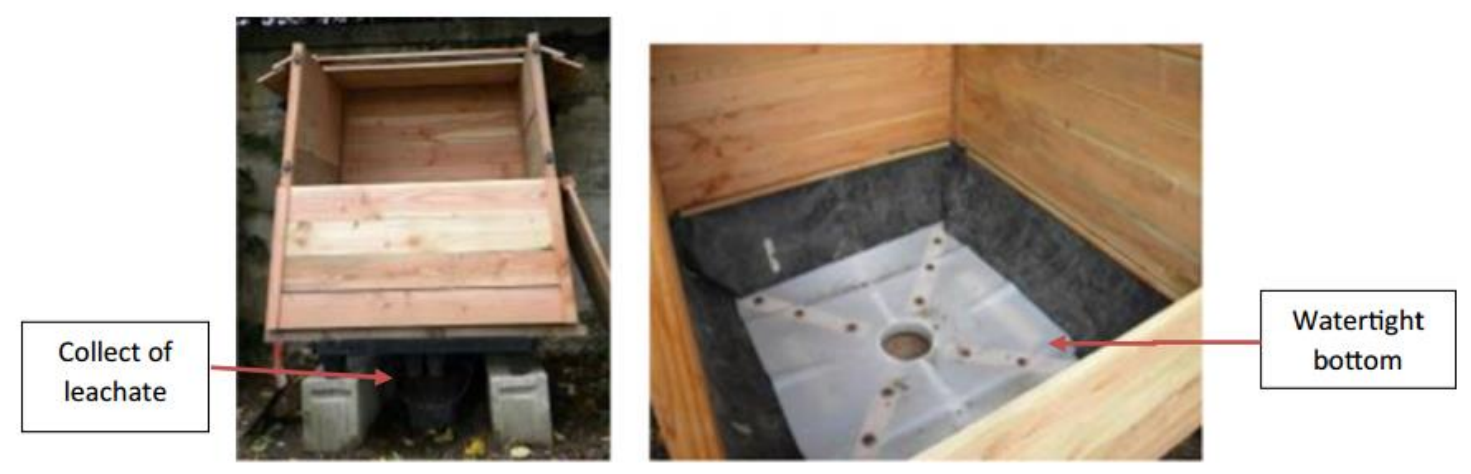

Fig. 2 Composter with watertight inner bottom to collect the leachates

Table 1 General information of pilot sites in France

\begin{tabular}{llllll}
\hline $\begin{array}{l}\text { Location } \\
\text { name }\end{array}$ & $\begin{array}{l}\text { No. of } \\
\text { adults }\end{array}$ & $\begin{array}{l}\text { No. of } \\
\text { child }\end{array}$ & $\begin{array}{l}\text { No. of } \\
\text { FWLCT }\end{array}$ & $\begin{array}{l}\text { Management } \\
\text { practice }\end{array}$ & $\begin{array}{l}\text { Watertight } \\
\text { bottom }\end{array}$ \\
\hline Nyons & 2 & 2 & 1 & Minimum & Yes \\
Plédran & 2 & 3 & 2 & Minimum & Yes \\
Kergrist & 2 & 2 & 1 & Minimum & No \\
Landévant & 2 & 2 & 2 & Optimized & Yes \\
$\begin{array}{l}\text { Gigondas } \\
\text { St. }\end{array}$ & 2 & 1 & 1 & Optimized & Yes \\
\multicolumn{1}{c}{$\begin{array}{l}\text { Barthél- } \\
\text { émy }\end{array}$} & 2 & 1 & Optimized & No \\
\hline
\end{tabular}

\section{Temperature}

Temperature measurement was done and the results were interpreted for the compost. The temperature was monitored by two methods: by the installed thermo-buttons inside the composters (three thermo-buttons per composter) and by the manual measurements with a compost thermometer.

The thermo-buttons are in steel and are $17 \mathrm{~mm}$ in diameter and $6 \mathrm{~mm}$ thick. They are resistant to temperatures between -40 and $85^{\circ} \mathrm{C}$ with a resolution of $0.5^{\circ} \mathrm{C}$. They have 1 year of autonomy and can record 2000 readings.

To obtain a much reliable transcription of the average composting conditions in wooden composters, they were distributed, on a lattice type mesh (Fig. 4). The first thermobutton was placed at $15 \mathrm{~cm}$ from the composter bottom; the second one was at its center and the last one at $10 \mathrm{~cm}$ from the top of the outside edge. 
The manual measurements of temperature were done weekly, and the households achieved this task with a compost thermometer.

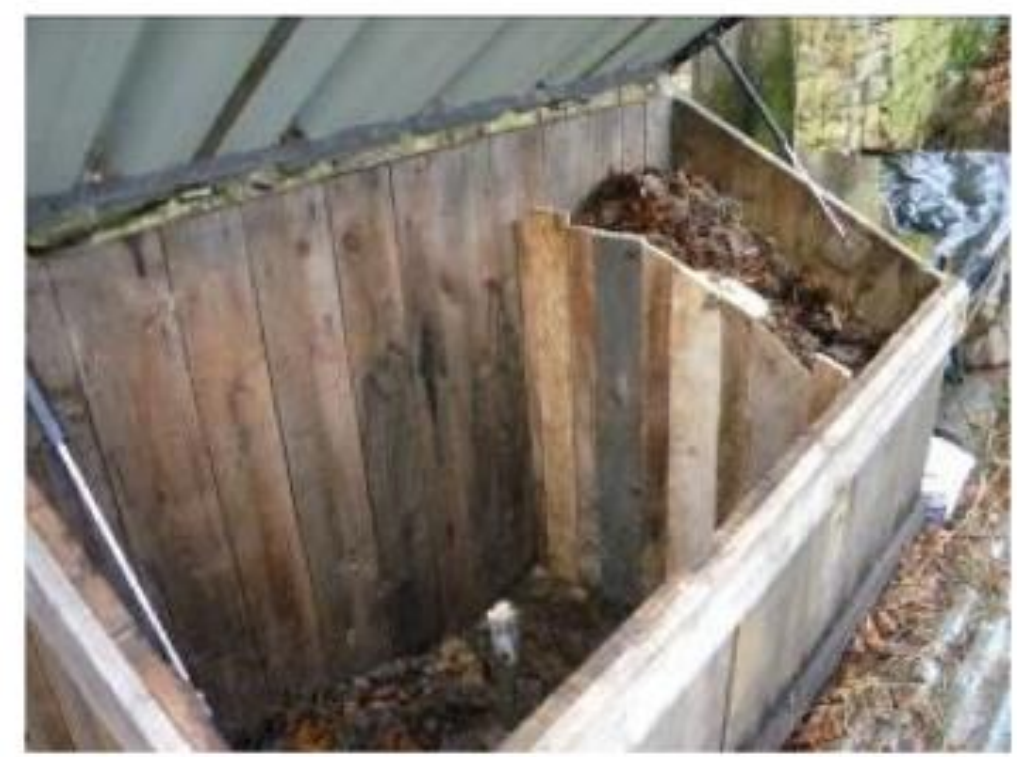

Fig. 3 Composter at St. Barthélémy, free bottom with optimized management. The small container (right) is for stocking the litter

\section{In situ chemical indicators}

The coulometric measurements were made on the leachate samples to determine their chemical properties. The measured parameters were the following: nitrate $\left(\mathrm{NO}_{3}\right)$, nitrite $\left(\mathrm{NO}_{2}\right)$, ammoniac $\left(\mathrm{NH}_{3}\right)$, and ammonium $\left(\mathrm{NH}_{4}\right)$. At the beginning of the study, a high concentration of ammonium was observed.

\section{Laboratory measurements}

\section{Compost sampling}

To monitor the bacterial evolution of the microbiological indicators of sanitation throughout the composting process, three sampling campaigns are carried out during the 12 months of the composting phase (initial state: end of emptying, 6 months of composting, end of the period: 1 year of composting).

These samplings are made according to the fourth method: all the materials are divided into four heaps of the same volumes, on a practical and protective sterile plastic. Two of these heaps are gathered and homogenized to form a new heap, which is again divided into four heaps of the same volumes. This operation is repeated four times. This sampling method makes it possible to obtain a homogeneous and representative sample of the composting materials. The sample is sieved with a 1-cm mesh, and the passing compost is packed in thick, new, hermetic, and opaque bags.

\section{Leachate sampling}

For the four composters with leachate sampling facilities, the leachate samples were directly collected in bottles which were situated in the bottom of the composters. The samples were packed in new and clean flasks. During each of the three sampling campaigns, two samples of $1 \mathrm{~L}$ of leachate were collected from each composter. One sample was used for microbiological analysis and the second one for the physicochemical analysis. The sampling procedure is as follows: weigh the bottle of leachate, carry out the colorimetric tests, stir in the bottle to re-establish the suspension and homogenize the deposited matter at the bottom of the bottle, carry out two samples of $0.5 \mathrm{~L}$, and evacuate the remaining leachate in the sanitation system of the habitat. It is not allowed to pour it again in the composter. The samplings were carried out at the beginning of the week, and the samples wereconserved by eutectic plates (cold condition). 


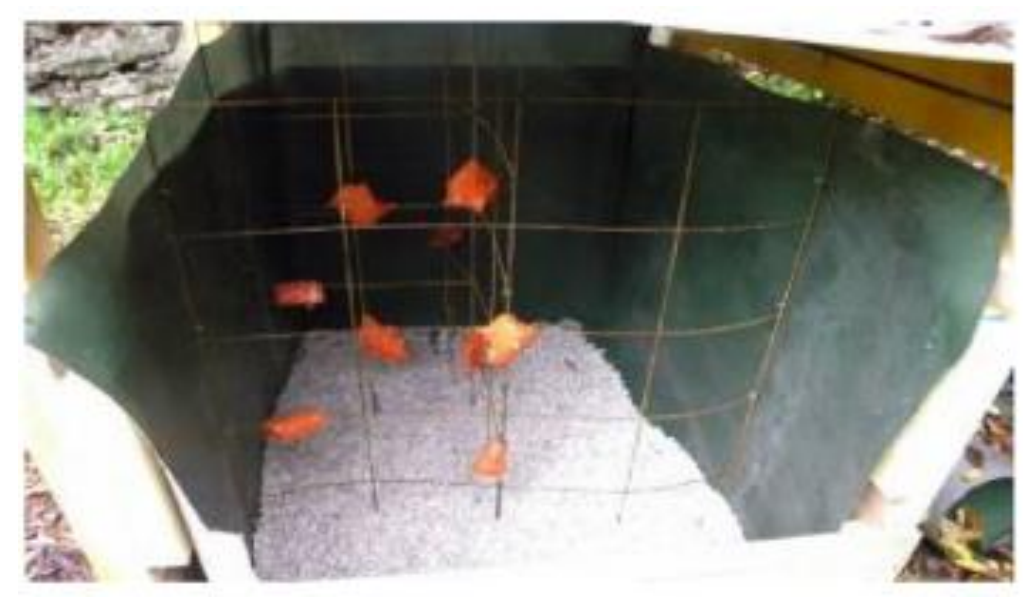

Fig. 4 Implantation of the thermo-buttons protected by tape and a watertight shell

\section{Chronology and description of the tests}

For the compost, the first sampling was carried out following the last fecal intake (in June 2013), the second, 6 months after the start of composting (December 2013). The samples of approximately $1 \mathrm{~L}$ (in duplicates) were taken for the tests.

The tests effectuated on samples of approximately $1 \mathrm{~L}$ (in duplicates) were the following: $\mathrm{pH}$, dry matter, and moisture content. Microbiological measurements were done according to French national standards: anaerobic germs (sulfitereducing) at $37{ }^{\circ} \mathrm{C}$, spore of ASR bacteria at $37{ }^{\circ} \mathrm{C}$, Escherichia coli, fecal enterococci, and Clostridium perfringens (two methods).

The last campaign was in June 2014 (1 year after composting). A third sample was added to analyze the following agronomic parameters: organic matter, total carbon, total nitrogen (NTK), potassium oxide $\mathrm{K}_{2} \mathrm{O}$, and phosphorus pentoxide $\mathrm{P}_{2} \mathrm{O}$.

Concerning the leachate, three laboratory campaigns were carried out during the study in January, March, and May 2013, respectively. The physicochemical measurements were the following: pH measurement, suspended matter, chemical oxygen demand (COD) and 5-day biological oxygen demand (BOD5), Kjeldahl nitrogen measurement (used as an estimator of total nitrogen), ammonium, ammoniac, nitrate, and nitrite. Microbiological measurements were as follows: anaerobic germs (sulfite-reducing) at $37{ }^{\circ} \mathrm{C}$, Escherichia coli, and Clostridium perfringens (two methods).

\section{Results and discussion}

As explained in the material and method, the results of this study have been divided in two components: one for the compost and the other for the leachate.

\section{Compost analysis results}

\section{Compost input rate}

Filling the composters started from December 2012 to June 2013. The mean volume of each evacuation bucket of FWLCT was 10 to $12 \mathrm{~L}$, where the emptying time interval between two evacuations was 4 days. The bucket contained feces, urine, and some litter (input mas). The mass of the added litter was known (total litter mass). At each emptying of the buckets, some more litter was added at the top of the matter in the composters (cover litter mass). The litter types used by the FWLCT were different. They vary from the sawdust of different trees to woodchips and softwood.

Measuring these rates is important because firstly, they are parameters for the dimensioning of the composters and secondly, they influence the compost quality and the time given to composting (Wichuk and McCartney 2010).

Input rate of composters during the period of study demonstrate a linearity behavior. So, while observing a linear regression (for all six sites $\mathrm{R}_{2}=99 \%$ ), it was possible to estimate the daily input rate of excretes in the composters for each site (Table 2). The excrete input rate presents a significant difference among the households (1.73 to 3.37 
$\mathrm{kg} /$ day). The first compost sampling was done at the end of the last addition of excreta in June 2013, and the last one was done 1 year after.

\section{Compost temperature}

As mentioned, the temperature of the composters was measured by two ways. One, continuously, was by the thermobuttons from 8 December 2012 to 8 December 2013 (filling phase of the composters +6 months of composting), and the other way was the manual punctual records by a compost thermometer.

According to the variation of the temperature in the composters, it can be inferred that in all sites, the temperature increases with time and always above the ambient temperature. This increase continues till the end of filling phase (0 to 6 months), and it does not exceed $35^{\circ} \mathrm{C}$. Also at this point, it does not endure. After this peak, it decreased with the time.

Table 2 Average input rate (kg/day) of composters for the pilot sites

\begin{tabular}{|c|c|c|c|c|c|}
\hline Site & $\begin{array}{l}\text { No. of } \\
\text { input } \\
\text { days }\end{array}$ & $\begin{array}{l}\text { Total } \\
\text { input } \\
\text { rate (kg/ } \\
\text { day) }\end{array}$ & $\begin{array}{l}\text { Total litter } \\
\text { (FWLCT) } \\
\text { mass (kg) }\end{array}$ & $\begin{array}{l}\text { Cover litter } \\
\text { (straw in } \\
\text { composter) } \\
\text { mass (kg) }\end{array}$ & $\begin{array}{l}\text { Excretes } \\
\text { input rate } \\
\text { (kg/day) }\end{array}$ \\
\hline Nyons & 183 & 2.45 & 46.5 & 3.5 & 2.19 \\
\hline Plédran & 156 & 3.32 & 144.4 & 13 & 2.52 \\
\hline Kergrist & 172 & 3.99 & 122.7 & 22.3 & 3.31 \\
\hline Landévant & 183 & 5.20 & 330 & 16.5 & 3.37 \\
\hline Gigondas & 159 & 2.02 & 53 & 18 & 1.73 \\
\hline $\begin{array}{l}\text { St. } \\
\text { Barthél- } \\
\text { émy }\end{array}$ & 168 & 2.79 & 58 & 5 & 2.40 \\
\hline
\end{tabular}

Composting toilets usually follow a temperature profile which is as follows: (a) a rapid initial increase to thermophilic temperatures, (b) a sustained high-temperature period, and (3) a subsequent decline to near-ambient temperatures. The initial rise and elevated temperature period is caused by exothermic reactions associated with microbial degradation of the readily biodegradable organic matter in the compost feedstock. The subsequent decrease in temperature ideally occurs due to a decrease in microbial activity as easily biodegradable substrate is consumed and more bio-resistant compounds, such as cellulose and lignin remain (Wichuk and McCartney 2010). In our pilot sites, the described chronic of temperature for composting (Wichuk and McCartney 2010) was observed. Also, a return of temperature to the ambient air temperature was observed which is in accordance with Haug and Haug (1993) and Lasaridi et al. (2000), who suggested that a temperature decline to near-ambient may indicate that the compost is approaching a stable and mature state (proved that reheating does not occur upon turning the pile).

The results indicate that the temperatures at the center of the compost (middle-top) are the hottest with the greatest inertia than the temperatures measured at the edges of the composters which are affected by the outside temperature. Composts therefore have an insulating role. Since, this elevated temperature is concentrated in the central part of the compost, mixing and turning can be used to create a more uniform temperature (Huang 1993; Epstein 1997). Turning can also increase the temperature (Vinneras et al. 2003). This is exactly what was observed concerning the difference of temperature in the pilot sites with optimized (mixing) and minimal management. Optimized management sites appear to have a rise in temperature which is more rapid than those with minimal management.

An elevated temperature justifies a good aerobic composting and guaranties a reasonable microbial activity. In the composting pilot sites, the observed temperatures were higher than ambient air and can prove some activities. Even so, the highest composting temperature achieves $35^{\circ} \mathrm{C}$ which is lower than the optimized composting temperature $\left(60{ }^{\circ} \mathrm{C}\right)$. In one hand, this low temperature goes well with the research results of Smith (1981) who states that generally, continuous addition compost toilets have pile temperatures between 20 and $35^{\circ} \mathrm{C}$. But in another hand, a continuous enough elevated temperature was not observed to assure a high degree of hygiene of the produced compost. 
However, the pile (composter) temperatures might be affected by factors such as ambient conditions (particularly in cold climates), pile size, extreme temperatures during the thermophilic phase, lack of free air space, oxygen depletion, drying, and excessively high moisture. In our study, the piles were relatively small. Larger piles cool more slowly than small piles, under similar environmental conditions, since their lower surface area to volume ratio provides more thermal insulation. This could be misleading; a small pile that has cooled may not be mature, while a large pile that is still warm may be stable (Mathur et al. 1993; Lasaridi et al. 2000).

In this study, oxygen depletion or moisture loss would slow microbial activity and lead to «premature » pile cooling (Adani et al. 2006; Brewer and Sullivan 2003). Likewise, very high pile temperatures (for example over $70{ }^{\circ} \mathrm{C}$ ), which is not our case by the results of this study, may destroy beneficial compost microflora. Microbial activity would thus be reduced, and the pile would cool even though it remained readily degradable compounds (Iglesias Jiménez and Pérez Garcia 1991; Lasaridi et al. 2000).

Several scientific researches demonstrated the contradictory results about the impact of the temperature on the compost quality. Li et al. (2004) demonstrated that temperature becomes stable before the stability of the inorganic matter transformations. They showed that the initial temperature decrease was due to dehydration. In a study done by Hsu and Lo (1999) on separated pig manure compost, pile temperatures had moved to decrease to ambient air temperature after 27 days, but the compost was not matured and stable until after 80 days of composting. According to the research of Flynn and Wood (1996), further losses in overall mass, carbon, and nitrogen content even after decreasing of temperature in the piles were observed. Chefetz et al. (1996) attained a stable product after 110 days of composting; however, the pile reached ambient temperatures after only 60 days. Inbar et al. (1993) also showed that the decomposition of matter continued, but slower, after pile temperatures returned to ambient levels (after 60 days of composting). Following California Integrated Waste Management Board (2007), compost with a temperature of $8{ }^{\circ} \mathrm{C}$ above ambient temperature is always in composting level. But it does not mean that pile temperatures within $8{ }^{\circ} \mathrm{C}$ of ambient temperature indicate the ending of composting.

Because of these arguments and the probability of false deduction of composting level according to the temperature evolution, it is not practical to consider composting pile temperature as an indicator of the compost quality and stability. As mentioned, temperature can be an index of compost process performance, and it must not be used alone.

\section{Compost $p H$}

The compost $\mathrm{pH}$ measurements show near or similar trends for the six study areas (Fig. 5). A rather basic phase is followed by acidification of the compost. The basic phase is explained by the high presence of urea and ammonia at the end of the filling. Then, the composting process is associated with an acidification of the compost due to the degradation of the carbonaceous material into organic acids by the microorganisms of the medium which theoretically must return to a neutral (slightly basic) $\mathrm{pH}$ at the end of the composting process. Indeed, all $\mathrm{pH}$ values tend to decrease and then rise during the 12 months of the composting phase.

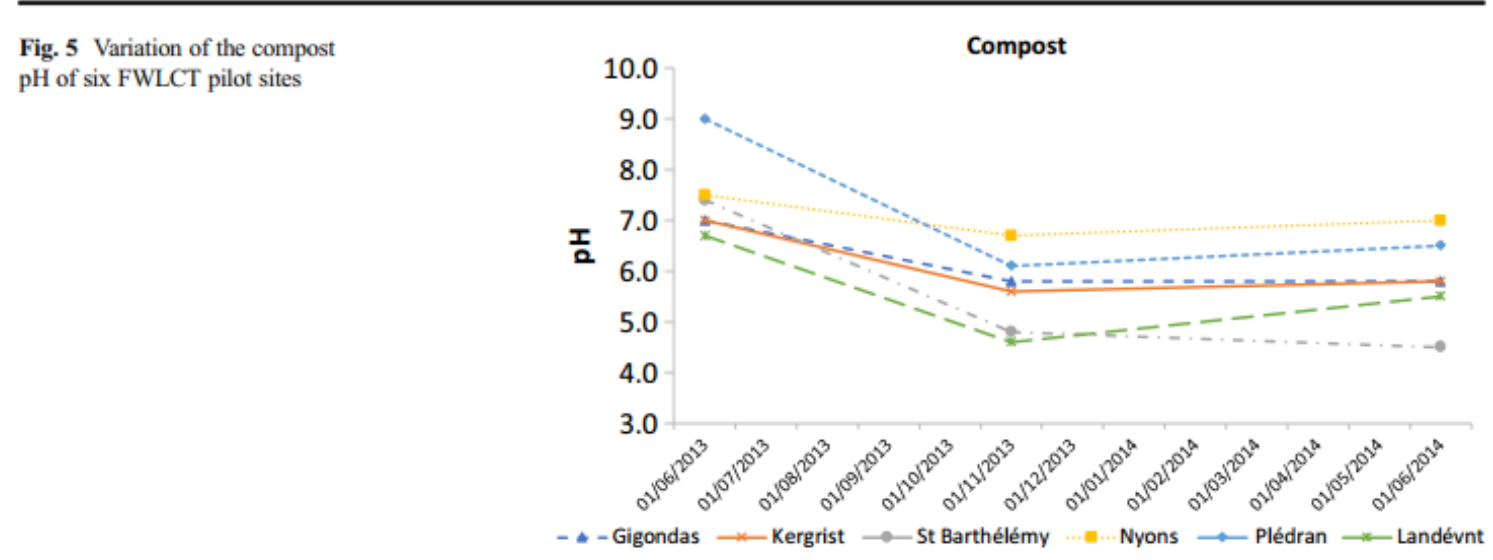

At 6 months of treatment, the $\mathrm{pH}$ values are all too acid, which is not a conventional aerobic treatment process compared to bio-waste composting. 
A cross-analysis with the type of litter employed shows that regardless of the species of carbonaceous material employed, there is no influence on the $\mathrm{pH}$. In parallel, the degradation of the organic nitrogen molecules to ammonia increases the $\mathrm{pH}$. This phenomenon starts to be observed during the last campaign ( $\mathrm{pH}$ rise) at certain sites. Thus, the decomposition of organic matter does not seem to be complete after 1 year of maturation.

Normally, as the compost matures, the ammonia is nitrified and the $\mathrm{pH}$ decreases. It is thought that a high $\mathrm{pH}$, therefore, may be indicative of high quantities of ammonia and hence immaturity. As composting progresses, the ammonia volatilizes and organic acids form which causes the pH to decrease again (Wichuk and McCartney 2010). Finally, organic acids become neutralized, which make the $\mathrm{pH}$ rise once more (Ko et al. 2008).

So, after 1 year of composting, we cannot approve the end of composting process by using the $\mathrm{pH}$ indicator. It means that, this technique of composting takes a long time and if we need compost rapidly, it is not a good method to use.

\section{Compost moisture content}

A relatively high moisture content $(\mathrm{H} \%)$ was observed, without being excessive, for all the sites (between 56.5 and $75.8 \%$ ) except in Gigondas, which regularly humidified its compost. The sites with minimal management see their moisture decrease whereas the sites with optimized management see their moisture remaining between 60 and $70 \%$ (Fig. 6). As mentioned, this moisture content contributes to the bacterial development required for composting.

The protection (watertight roof and walls) of all the composters in the study is particularly important to maintain a moisture content of more than $50 \%$ which is necessary for the composting process. Specifically, in the Mediterranean context, moisture adjustment is a plus.

The combination of high moisture and low $\mathrm{pH}$ values seems to inhibit the action of microorganisms which do not find favorable conditions to their development.

For the moisture contents that occur in compost, the air will be saturated. Unsaturated air surrounding the compost may dry out the edge of the pile and adversely affect microbial activity. This edge effect is not considered in large scale systems, but is important in compost toilets where continuous addition to the surface of the pile means much of the early breakdown occurs in this zone. This aspect can be considered in optimized management toilets, where the mixing can break this dry edge and create a microbial activity near the surface.

\section{Microbiology of the compost}

At all study sites, the microbiological values for Enterococci and E. coli are satisfactory as they tend to decrease during the composting process. The results showed that presence of Escherichia coli and Enterococcus decrease in the first year of composting. An unfavorable environment to their development has thus been created. On all sites, the number of Clostridium perfringens colony tends to decrease, but the number of spores remains variable. The continuous composting method applied at all sites is not entirely unfavorable to the maintaining of the C. perfringens bacterium in the environment. These results are in line with the empirical observations. In fact, these resistant bacteria, especially at rising temperatures, are present naturally in the soil; their eradication is difficult (only liming with a high concentration allows a reduction between 2 and $5 \log$ ).
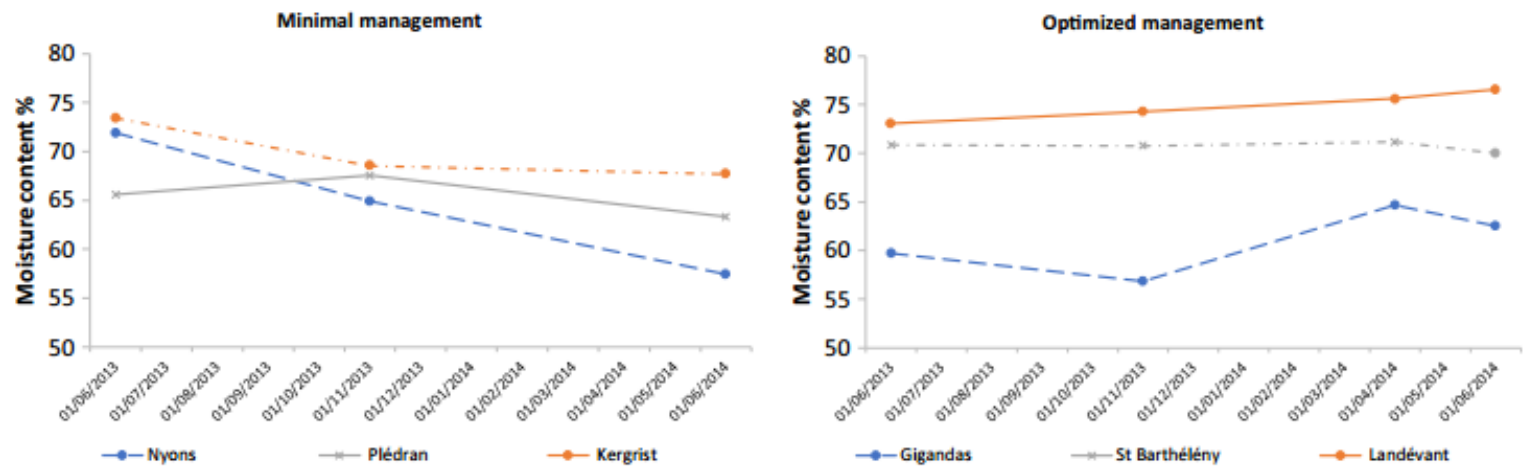

Fig. 6 Moisture content $(\%)$ variation in the compost piles during the study period 
Concerning the pathogens, Wichuk and McCartney (2010) state that there are no regulations specifically for decentralized human compost (including FWLCT). But temperature and time are often the primary criterion used to determine if the compost is safe for use as a fertilizer. To inactivate microorganisms, we need a temperature of 55-65 ${ }^{\circ} \mathrm{C}$ and composting at $55^{\circ} \mathrm{C}$ can eliminate Escherichia coli within 3 days (Grewalet al. 2006). Apart from elevated temperatures, pathogens are also killed due to competition with thermophilic microbes which resist elevated temperature (Feachem et al. 1983). An indicator of time and temperature combination can be used to evaluate pathogen elimination. Feachem et al. (1983) suggested time-temperature combinations of $1 \mathrm{~h}$ at $>62^{\circ} \mathrm{C}$, 1 day at $>50{ }^{\circ} \mathrm{C}$, and 1 week at $>46{ }^{\circ} \mathrm{C}$ for pathogens to be eliminated in composting human waste. Depledge (1997) reported that 1 month of $44{ }^{\circ} \mathrm{C}$ temperature or 12 months of $43{ }^{\circ} \mathrm{C}$, temperature can be sufficient to kill all pathogens.

In this study, the observed composting process does not satisfy the above criteria. However, regardless of the site, it can reduce the thresholds of microbiological parameters. Given the evolution of the resistant forms of C. perfringens which are not eliminated or even significantly reduced below a significant threshold (from 3 log) by the current composting at the end of 1 year, it is possible that other pathogens such as parasites are also present.

The duration of 1 year of composting does not make it possible to evaluate the power of the composting process to eliminate C. perfringens in FWLCT installations. Lastly, the observed abatements are not sufficient to qualify the composts as a hygienist and high quality. It is no longer possible to conclude about a direct impact of the management of composters on the abatement of the monitored microbiological parameters.

\section{Composition of compost substrate}

Human feces are a mixture of food that has not been digested, body waste products such as bile from the liver and a part of the intestinal flora; $70-86 \%$ is water. The mixture is $14-30 \%$ bacteria and $25-40 \%$ food residues. The food residues are mostly indigestible cellulose and hemicellulose as simple sugars are not excreted by healthy adults (Chapman 1993). There are the nutriments in human excreta which could be served as fertilizers to enrich the soil. To evaluate the fertile level of produced compost, nutriment parameters of the compost in all sites have been measured (Table 3). These parameters are as follows: moisture content (H), solid matter (SM), organic matter $(\mathrm{OM})$, total carbon $\left(\mathrm{C}_{\text {tot }}\right)$, total Kjeldahl nitrogen $\left(\mathrm{N}_{\mathrm{tk}}\right)$, carbon to nitrogen ration $(\mathrm{C} / \mathrm{N})$, potassium oxide $\left(\mathrm{K}_{2} \mathrm{O}\right)$, and phosphorus pentoxide $\left(\mathrm{P}_{2} \mathrm{O} 5\right)$.

Regarding the time interval between the last addition of fresh excreta made by bucket and the last compost sampling which is 1 year after, it should be noted that just one measure of nutriment parameters has been done in this study and it was for the final compost (after 1 year composting). So, a monitoring of the organic matter evolution which would have made it possible to obtain data on the level of biodegradation and on the aerobic character of the biodegradation was not done.

Table 3 Physical properties of the compost nutriment content in study sites

\begin{tabular}{|c|c|c|c|c|c|c|}
\hline Parameter & Nyons & Plédran & Kergrist & Landévant & Gigondas & St. Barthélémy \\
\hline $\mathrm{H}(\%)$ & 58.0 & 64.1 & 68.3 & 75.8 & 61.1 & 69.4 \\
\hline $\mathrm{SM}(\%)$ & 42.0 & 35.9 & 31.7 & 24.2 & 38.1 & 30.4 \\
\hline OM (\%) & 37.3 & 34.0 & 39.3 & 23.2 & 34.6 & 26.8 \\
\hline $\mathrm{C}_{\mathrm{bot}}(\%)$ & 18.6 & 16.4 & 14.0 & 11.1 & 17.0 & 12.4 \\
\hline $\mathrm{N}_{\mathrm{tk}}(\%)$ & 0.79 & 0.64 & 0.56 & 3.3 & 0.56 & 0.37 \\
\hline $\mathrm{C} / \mathrm{N}$ & 23.5 & 25.6 & 25.0 & 33.6 & 30.4 & 33.5 \\
\hline $\mathrm{K}_{2} \mathrm{O}(\%)$ & 0.59 & 3.6 & 0.29 & 0.20 & 0.50 & 0.15 \\
\hline $\mathrm{P}_{2} \mathrm{O}_{5}(\%)$ & 0.67 & 3.2 & 0.32 & 0.70 & 0.61 & 0.24 \\
\hline
\end{tabular}

The average of final $\mathrm{C} / \mathrm{N}$ ratio for the sites is 28.6 which cannot directly be used to interpret the composting quality. That is because of the lack of data for initial $\mathrm{C} / \mathrm{N}$ state of the compost. It is the decline in the $\mathrm{C} / \mathrm{N}$ ratio during the process which attests a degradation of materials with loss of carbon. The thresholds for compost $\mathrm{C} / \mathrm{N}$ ratio have been proposed after several researches. This ratio for the mature compost varies from $<20$ to $<10$ (Wichuk and McCartney 2010). Obviously, the $\mathrm{C} / \mathrm{N}$ of the compost in this study is much higher than the proposed values. But, as argued by Wichuk and McCartney 2010, using C/ N ratio for the compost quality is limited by some factors. The microorganisms can fix nitrogen which can cause an increase in nitrogen of the compost. In addition, variation of $\mathrm{C} / \mathrm{N}$ ratio is related to other parameters such as $\mathrm{pH}$. In neutral $\mathrm{pH}$ condition, carbon loss as $\mathrm{CO}_{2}$ and nitrogen 
loss as $\mathrm{NH}_{3}$ are in a competition, and it can cause stability in evolution of $\mathrm{C} / \mathrm{N}$ ratio during composing. In the other hand, in waterless composting toilets, since the carbon to nitrogen ratio of excreta $(\mathrm{C} / \mathrm{N}=8)$ is deficient in carbon, a large amount of carbon has to be added to the compost pile to adjust the carbon to nitrogen ratio. Fresh grass cuttings, wood chips, and kitchen wastes are examples of high carbon content bulking materials. Fresh grass cuttings and leaves have a carbon nitrogen ratio of 15:1. Dried leaves might have an even higher ratio (Depledge 1997). Toilet paper has a carbon to nitrogen ratio of 200-350/1(Compost ingredients 2012). So, the variation of $\mathrm{C} / \mathrm{N}$ ratio depends on the litter type we use to the excreta in the compost piles. All these arguments make it difficult to place an absolute limit on $\mathrm{C} / \mathrm{N}$ ratio that will be applicable to all litters.

Regarding the organic matter, all sites comply with the current standard (NFU 44-095,> 20\% on MB), whereas the results obtained for the dry matter are rather low for all the study sites ( $<50 \%$ on $\mathrm{MB})$. In a study, Wu et al. (2000) concurred that OM makes a poor indicator of stability and maturity, as they did not observe any consistent trends in total volatile solid content during bio-solid composting.

The obtained values for the three fertilizing elements, nitrogen, phosphorous, and potassium compounds (NPK), showed that the produced compost is a poor fertilizer $(>1 \%)$ but are close to the reference regulation (NFU 44095 2004) for use of the compost as an organic amendment. Also, these values are relatively close to those of biowaste composting (although lower values are observed for the site of St. Barthélémy certainly due to its high humidity). Despite these low levels, the produced compost can be used as soil amendment. In fact, it improves the physical and chemical properties of the soil and consequently gives a better crop yield.

According to Depledge (1997) (Table 4), human excreta contains a greater quantity of nutrients than the obtained compost in this study. So, the harvested compost in this study cannot be considered as a soil fertilizer, but it can only be added to soil as a soil conditioner. It means that this compost can only benefit some soils by making them easier to cultivate and by improving their moisture holding capacity.

\section{Leachate analysis results}

The analysis of the leachate (physicochemical and microbiological) should permit to assess the environmental and health quality of the leachate. In this research, the flux of pollutants per unit of excreta mass and per user of each waterless toilet, was evaluated.

\section{Leachate production rate}

The cumulated leachate masses during the study were measured regularly. The results show a very linear trend of leachate accumulation in the bottles (Table 5).

The average mass of daily produced leachate varies between 0.85 and $1.79 \mathrm{~kg} / \mathrm{day}$. It should therefore be noted that, in all cases, the volume of drained liquid is greater than the retention capacity of the compost mass. This retention capacity is also constant regardless of the thickness of the compost. It is therefore likely that the compost will be kept at its field capacity for the duration of the filling. So, it is obvious that if there is no drainage of leachate in the piles, liquid accumulation submerges the pile and anaerobic conditions occur, with associated odors.

Table 5 Mass of leachate production by each site

\begin{tabular}{ll}
\hline Site & Leachate rate $(\mathrm{kg} /$ day $)$ \\
\hline Nyons & 0.90 \\
Plédran & 0.85 \\
Landévant & 1.79 \\
Gigondas & 0.90 \\
\hline
\end{tabular}

All houses were occupied permanently, but just in the site of Landévant, there was a building construction action. The construction activities of explain a priori the quantity of leachates higher than the other sites. The produced leachate masses can be compared to the compost and excreta masses (Table 6). It can be seen that a fraction of the mass deposited in the composters flows in the form of leachates (between 23 and $47 \%$ of the total mass of compost which is equal to 27 and $66 \%$ of the mass of excreta). 
Table 6 Percentage of leachate form the compost and excreta masses

\begin{tabular}{lll}
\hline Site & Leachate/compost (\%) & Leachate/excreta (\%) \\
\hline Nyons & 35 & 40 \\
Plédran & 23 & 27 \\
Landévant & 37 & 66 \\
Gigondas & 47 & 56 \\
\hline
\end{tabular}

Concerning the specific case of Landévant, the large production of leachates in relation to the total mass of excreta can probably be attributed to a large amount of urine related to man working during building activities (also, we noted two punctual events of flooding of compost pile due to the compost cover flown over two storms). It can be noted that the use of a large mass of litter does not seem to make it possible to significantly improve the retention of liquid in the compost.

These data which concern the mass balance of the compost and the production of leachates show a significant leachate production (between 25 and 50\% of the introduced mass into the composters). These volumes of liquid can be considered as surplus and could be a priori, diminished by a partial separation of the urines (for example build urinals for men) without harming the condition of composting.

None of the FWLCT of this study is a urine separated system. A statistical analysis of the number and amount of passages to urinate and defecate in each FLWLCT demonstrates that the average of the mass of urine and feces by passage is 187 and $93 \mathrm{~g}$, respectively. The advantage of this result lies in the possibility of estimating the proportion of urine drained from the composter as leachate. From the 154 days that could have been taken into account for this analysis, the total urine mass excreted is estimated at $276.6 \mathrm{~kg}$ and can be compared to the leachate mass of $138.6 \mathrm{~kg}$ collected on that date. It can therefore be estimated that about $50 \%$ of the urine is not retained in the composter and thus constitutes the basis of the leachate. Separate collecting and treatment, at least partially, of urine would make it possible to limit leachate production very strongly while preserving satisfactory humidification of the compost.

\section{Leachate flux estimations}

By using the flux of the leachate, we can calculate the flux of the chemical elements and contaminants in a treatment system or in the natural receptor medium.

In the context of FWLCT, an estimation can be made by considering that the infiltration surface corresponds to the surface ( $\mathrm{S}$ ) of the composter (i.e., $\mathrm{S}=1 \mathrm{~m} 2$ ). Two flux values were calculated. The first one is the time distributed flux (qd) which considers the leachate flux as uniformly distributed over a parameter of time (Eq. 1):

$$
q_{d}=\frac{P}{\rho_{L} \times S \times T_{1}}
$$

where $\mathrm{P}$ is the daily leachate production (Table 5), $\rho$ L is the bulk density of the leachate $(1000 \mathrm{~kg} / \mathrm{m} 3), \mathrm{S}$ is the crosssection surface of the composter $(1 \mathrm{~m} 2)$, and $\mathrm{T}_{1}$ is the 1-day duration in second.

The second one is a rapid flux ( $\mathrm{qr}$ ) which is estimated from the empirical observations of study participants. The very rapid leachate flux was observed during the first hour that follows the weekly emptying in the composter (Eq. 2).

$$
q_{r}=\frac{7 \times P}{\rho_{L} \times S \times T_{2}}
$$


Factor $« 7$ » reduces the average daily leachate production on a weekly basis and $\mathrm{T} 2$ is the duration of $1 \mathrm{~h}$ expressed in seconds. These two flux values define a representative range of the leachate flux that can be emitted into the soil from the composters. They are presented in Table 7.

\section{Leachate total suspended solids}

Total suspended solids (TSS) represent all the solid particles present in the leachate. The mass concentration measurements which were obtained from laboratory tested samples are shown in Fig. 7.

TSS concentrations demonstrate that the value of suspended solids generally shows a decreasing trend over time. This indicator shows an increase in the filtration phenomenon in the compost pile. As the thickness of the compost crossed by the leachate increases during the filling phase of the composter, the probability of trapping particles during percolation tends to increase.

Table 7 Leachate flux estimation of the composters

\begin{tabular}{lll}
\hline Site & Time distributed flux $(\mathrm{m} / \mathrm{s})$ & Rapid flux $(\mathrm{m} / \mathrm{s})$ \\
\hline Nyons & $1.0 \times 10^{-8}$ & $1.75 \times 10^{-6}$ \\
Plédran & $9.8 \times 10^{-9}$ & $1.65 \times 10^{-6}$ \\
Landévant & $2.1 \times 10^{-8}$ & $3.5 \times 10^{-6}$ \\
Gigondas & $1.0 \times 10^{-8}$ & $1.75 \times 10^{-6}$ \\
\hline
\end{tabular}

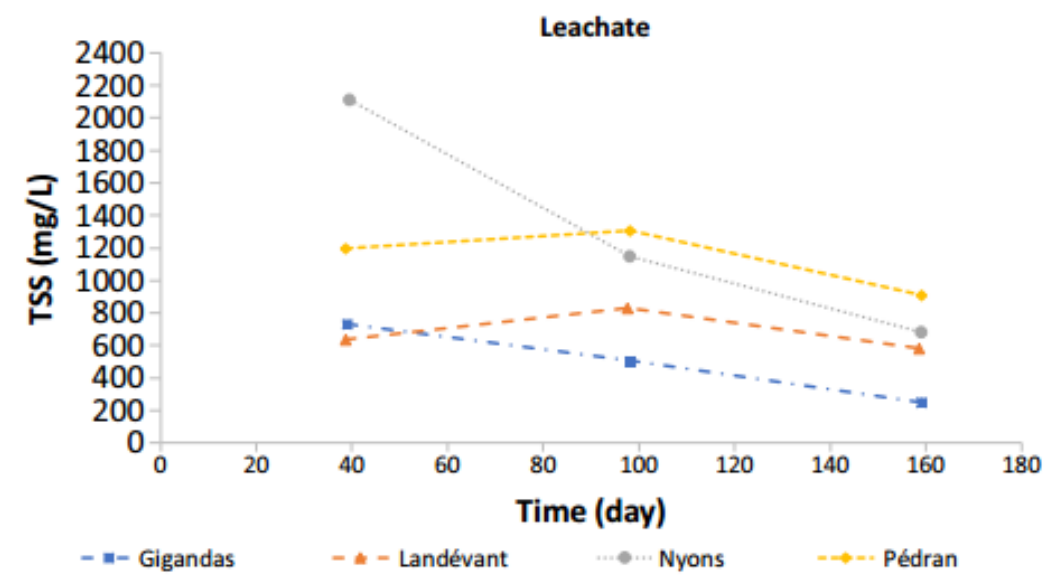

Fig. 7 Variation of total suspended solid concentration in the leachate of four sites

Leachate organic matter reduction

The organic matter introduced into the composter is likely to evolve over time due to its biochemical degradation. The chemical oxygen demand (COD) is an indicator of the presence of total organic matter in the leachate samples. Biological demand for oxygen (BOD) is an indicator of biodegradable MO (by microorganisms, in aerobic condition). The BOD/COD ratio is therefore an indicator of the nature of the MO: Values close to 1 correspond to poorly degraded (or fresh) MO while low values correspond to refractory MO (or at least largely degraded).

Figure 8 shows the evolution of this indicator over time from laboratory measurements. There is a remarkable tendency in COD decrease. The decrease in BOD is more sensitive and is well illustrated by the sharp decrease in the BOD/COD ratio for the four sites. 
Since the residence time in the collection bucket between two emptying is relatively constant, it is reasonable to assume that the concentrations of BOD and COD of the drained liquids remain fairly constant during the study. Under these conditions, the decreases observed for BOD, COD, and the BOD/COD ratio must be related to phenomena occurring in the composter. The distribution of organic matter between dissolved and particulate phases could not be determined in this study. Some of the observed decrease can be attributed to the filtration phenomenon, which appears to lead to a decrease in TSS (Fig. 7).

However, this phenomenon does not, on its own, explain that the decrease in the biodegradable fraction (BOD) is significantly greater than that of the TSS and the COD. The organic matter present in the leachate is therefore significantly more refractory at the end of the filling. This observation reflects biodegradation activity. This can take place during leachate percolation, which is longer when the compost is filled. A decrease in BOD in leachates is also observed in the composting of green waste (Savage and Tyrrel 2004).

\section{Nitrogen and $\mathrm{pH}$ in leachate}

Nitrogen compounds are a major challenge of the sanitation systems. Indeed, urea is present at a very high concentration in the urine. The release of nitrogen into the environment can have a considerable influence on the ecosystems. In addition, nitrogen has a complex cycle in the environment, and its various forms are very good indicators of the physicochemical conditions of the media (Heinrich and Hergt 1993). Nitrogen in nitric forms (nitrate and nitrite) was not detected in any of the laboratory or family samples. This constitutes, a priori, an indicator of reductive (anoxic) conditions in the collector buckets but also in the composters. This last point is less clearly demonstrated by these measurements because the percolation time between the leachates and the compost is relatively short. The nitrates which were possibly formed in the well-ventilated areas of the compost may not come into contact with the leachates (in the case of preferential flows) or be degraded to nitrogen gas by denitrifying bacteria.

The quantity of ammonium in the leachate over the time and the final concentration is rather stable and varies between 4 and $6 \mathrm{~g} / \mathrm{L}$. Also, comparison of concentration of ammonium with total nitrogen (Kjeldahl nitrogen) shows that degradation of urea is very efficient $(>80 \%)$. Given the low contact time of the leachate with the compost, this transformation probably takes place in the collection bucket during a few days between two emptying. The $\mathrm{pH}$ values which were obtained by the families are very stable and in agreement with the laboratory measurements. The very basic $\mathrm{pH}(=9)$ is quite consistent with the high concentrations of observed ammonium. The degradation of urea to ammonium tends to create $\mathrm{OH}$-ions at pHs below 9.25.

\section{Flux of the contaminants by FWLCT}

Measurements of the leachate flux made it possible to estimate the emitted fluxes towards the environment. Given the rather limited number of measurements in this study, the approach used to estimate flux of TSS, COD, BOD, and NTK is based on the following more stringent assumptions: the chosen concentrations are the highest measured values in all 12 analyses in the laboratory; the largest leachate production is taken into account (1.79 L/d) at Landévant site; the use of this mean value is justified by the very good observed linearity on the cumulative production of leachates; and the calculated fluxes correspond to four equivalent habitants $(\mathrm{EH})$ which are the case of the household living in the Landévant site. Table 8 shows the emitted flux by FWLCT, for some physicochemical indicators which are calculated and the associated normative values.

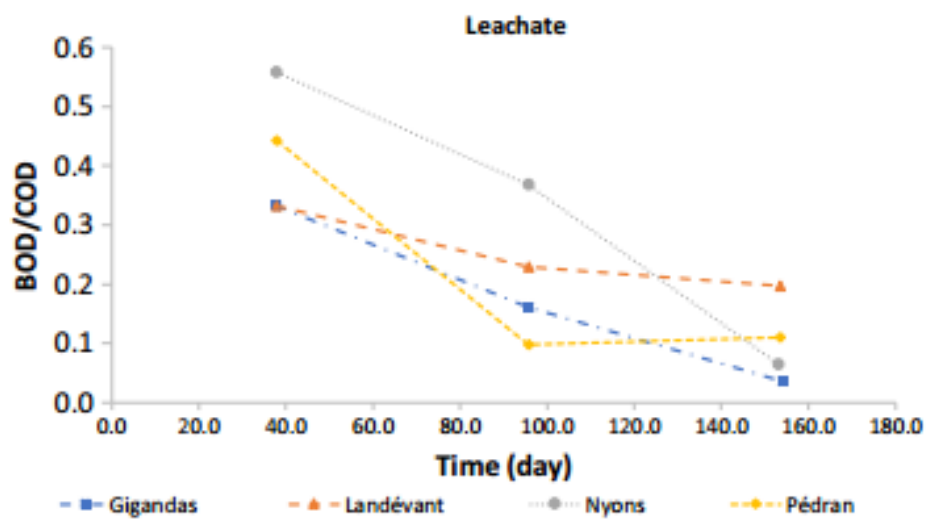


Fig. 8 Evolution of the BOD/COD relation during composting

Table 8 Leachate and contaminant daily flux by FWLCT

\begin{tabular}{lllll}
\hline Parameter $\begin{array}{l}\text { Concentration } \\
(\mathrm{g} / \mathrm{L})\end{array}$ & $\begin{array}{l}\text { Leachate } \\
\text { daily flux } \\
\text { (L/day) }\end{array}$ & $\begin{array}{l}\mathrm{N}^{\circ} \text { of } \\
\text { habitants }\end{array}$ & $\begin{array}{l}\text { Parameter emission } \\
\text { by leachate }(\mathrm{g} / \text { day/ } \\
1 \mathrm{EH})\end{array}$ \\
\hline TSS & 2.12 & 1.79 & 4 & 0.95 \\
COD & 16.30 & 1.79 & 4 & 7.29 \\
BOD & 8.76 & 1.79 & 4 & 3.92 \\
NTK & 7.10 & 1.79 & 4 & 3.18 \\
\hline
\end{tabular}

\section{Microbiologic flux}

It seems delicate to draw a trend from microbiological measures. The point sources of microorganisms appear to be found in leachates. This behavior could be related to the existence of rapid leachate flow which is observed by the households. Given the very direct percolation of the leachate, these microbiological measurements are not sensitive to a possible composting effect. There is therefore no compost integrating effect on the leachate microbiology.

The results of microbiological analysis show that the quantity of enterococci exceeds the thresholds for collective sanitation standards for microbiological parameters, although, the levels of E. coli measured remains in the order of magnitude of the standard, but always in high quantities. Thus, the existence of the harmful bacteria in the leachate is confirmed, and it is possible to conclude on a specific impact of leachate on the human health and environment. It is therefore necessary to limit leachate handling actions to limit health risks.

\section{Conclusion}

In France, concerning domestic composting, regulations are limited. There are some texts mentioning/promoting this practice, such as the environmental charter adopted in 2005 which insists that we must preserve the environment for future generations and concludes that the act of composting, by reducing the volume of waste, is indeed a citizen act. The National Domestic Composting Support Plan (launched in 2006) and the circular of April 2007 (Circular 2007) on household waste management plans motivate communities to encourage individuals to engage in domestic composting. According to Brinton (2000), the regulations for compost management are nonuniform throughout the world due to a lack of strong scientifically proven information on how composting should be performed and what are the critical points for proper composting to ensure safety.

The implementation of an in situ study of waterless toilets with household association was well demonstrated. The physicochemical and microbial parameters of produced compost and leachate have been monitored for 1 year. It was important to underline the need for a coordination structure of the study which ensures the follow-up and accompaniment of the families and technical partners to avoid the dysfunctions.

One of the main problems of this system of human excreta treatment is that the process of treatment of solid byproducts which is of a 12-month duration (during this time no additional fresh organic matter was added to the composters) does not cause a significant rise in temperature and does not allow to reach the optimum temperatures $\left(>50^{\circ} \mathrm{C}\right)$. So, according to this result, the by-product which was obtained after 1 year of treatment, named compost, is not entirely hygienic; therefore, certain health precautions must be observed for all handlings. However, the researches (Abbott 2004; Winblad et al. 2004) acknowledge that household/backyard excreta composting may not reach high enough temperatures or may not be operated optimally, but it recommends some kind of secondary composting at a larger centralized systematically managed site so that pathogens will be eliminated and the compost will be fully sanitized.

From an agronomic point of view, the obtained compost is not rich enough in nutriments to be good compost as soil fertilizer. But it can be used as a soil structure conditioner. Soil structure is a key factor in the functioning of soil, its ability to support plant and animal life, and moderate environmental quality (Bronick and Lal 2004). The decline in soil structure is increasingly seen as a form of soil degradation and is often related to land use and 
soil/crop management practices. Soil structure influences soil water movement and retention, erosion, crusting, nutrient recycling, root penetration, and crop yield (Chan et al. 2003).

At 6 months of treatment, the $\mathrm{pH}$ values are all too acidic which is not a conventional aerobic treatment process compared to bio-waste composting. The « design » of the self-built composters allows to maintain a good moisture in the matrix but decreases its aeration. It is difficult to conclude about the impact of compost management. Based on these observations, it is not possible to confirm that the current process is characterized composting. It is therefore appropriate to call it a process for the treatment of waterless toilet products by storage.

For all the physicochemical indicators, the concentrations of the monitored parameters are higher than the discharge standards, but the associated flux is low. Nevertheless, a generalized reduction of these parameters is observed during 6 months of filling of the piles. BOD/COD and $\mathrm{pH}$ calculations show a biodegradation priming in the collection buckets. However, it is not possible to determine whether this degradation is aerobic or anaerobic.

Also, the composting processes produce regularly a leachate flux which contains some bacteria which come directly from human excreta. In any case, this leachate should be collected and oriented towards a wastewater treatment system. As the leachate is about $50 \%$ of the input urines by FLWCT, it is recommended to install a urineseparated system to reduce the amount of the leachate or to use other potential options like secondary treatment of leachate, evaporation of leachate with electricity or solar thermal energy, evapotranspiration beds, and constructed wetlands.

Finally, the composting piles in their actual state and management are not optimized enough to achieve higher sanitization. The recommendation cited by Jenkins (1999) must be considered as the orientation lines to construct and manage these types of piles.

One obstacle to poor adoption of composting toilets is the lack of awareness of this technology. One of the main reasons to this lack of awareness is few scientific researches on field performance of composting toilets, and especially, the achievement of optimum temperatures is immature and inconclusive (Anand and Apul 2014). So, an innovative effort is necessary for the design of the composting piles. For example, the systems should be designed so that the householder can control and change the temperature, moisture content, and the other parameters.

\section{Acknowledgments}

This research has been developed within the familial waterless toilet project undertaken by Toilettes Du Monde (TDM) with the support of French Agency of Environment and Energy Control (ADEME, grant no. 1106C0083). The authors are grateful to the owners of the houses for their participation in data collecting and the member of the Ecological Sanitation Network (Réseau de l'Assainissement Écologique-www.raeintestinale.fr). Thanks to LTHE laboratory (Grenoble, France) who permitted to develop the scientific protocols and to interpret the leachate analysis.

\section{References}

Abbott R (2004) Skaneateles Lake watershed, composting toilet project. Small flows Q 5(2):32-39

Adani F, Ubbiali C, Generini P (2006) The determination of biological stability of composts using the Dynamic Respiration Index: the results of experience after two years. Waste Manag (New York, N.Y.) 26(1):41-48

Anand CK, Apul DS (2014) Composting toilets as a sustainable alternative to urban sanitation-a review. Waste Manag 34(2):329-343

Bartram J, Sandy Cairncross S (2010) Hygiene, sanitation, and water: forgotten foundations of health. PLoS Med 7(11):1-9

Baum R, Luh J, Bartram J (2013) Sanitation: a global estimate of sewerage connections without treatment and the resulting impact on MDG progress. Environ Sci Technol 47:1994-2000

Bernal MP, Alburquerque JA, Moral R (2009) Composting of animal manures and chemical criteria for compost maturity assessment. A review. Bioresour Technol 100:5444-5453

de Bertoldi M, Vallini G, Pera A (1983) The biology of composting: a review. Waste Manage Res 1:157-176

Boulter-Bitzer JI, Trevors JT, Boland GJ (2006) A polyphasic approach for assessing maturity and stability in compost intended for suppression of plant pathogens. Appl Soil Ecol 34:65-81

Brewer LJ, Sullivan DM (2003) Maturity and stability evaluation of composted yard trimmings. Compost Science \& Utilization 11(2): 96-112 
Brinton WF (2000) Compost quality standards and guidelines: an international view. ME, Woods End Research Laboratory Inc Bronick CJ, Lal R (2004) Soil structure and management: a review.

Geoderma 124(1-2):3-22 California Integrated Waste Management Board (2007) Compost quality: performance requirements - matching performance needs with product characteristics [online]. Available from http://www.ciwmb. ca.gov/Organics/Products/Quality/Needs.htm

Chan KY, Heenan DP, So HB (2003) Sequestration of carbon and changes in soil quality under conservation tillage on lighttextured soils in Australia: a review. Aust J Exp Agric 43:325-334

Chapman PD (1993) Compost toilets: an option for human waste disposal at remote sites. Lincoln University. http://researcharchive.lincoln.ac.nz/handle/10182/3016

Chefetz B, Hatcher PG, Hadar Y, Chen Y (1996) Chemical and biological characterization of organic matter during composting of municipal solid waste.

J Environ Qual 25(4):776-785 Circular (2007) Règlementation française relative aux plans de gestion des déchets ménagers. http://www.ineris.fr/aida/consultation_document/7295Compost Ingredients (2012) http://www.thecompostgardener.com/compostingredients.html\#axzz22zsZdjAv> (accessed August 2012) (Unpublished Work)

Cordova A, Knuth B (2005) Barriers and strategies for dry sanitation in large-scale and urban settings. Urban Water J 2:245262

Del Porto D, Steinfeld C (1998) The composting toilet system book: a practical guide to choosing, planning and maintaining composting toilet systems, a water-saving, pollution-preventing alternative.Center for ecological pollution prevention, New York

Depledge D (1997) Design examples of waterless composting toilets. South Pacific Applied Geoscience Commission. Report 249. <http://www.pacificwater.org/userfiles/file/MR0249.pdf> (accessed February 2013)

Dharmabalan P (1988) Small waste disposal systems. Papua new guinea university of technology department of civil engineering, Papua

Dzwairo B, Hoko Z, Love D, Guzha E (2006) Assessment of the impacts of pit latrines on groundwater quality in rural areas: a case study from Marondera district, Zimbabwe. Phys Chem Earth Parts A/B/C 31(15):779-788

Enferadi KM (1981) A field evaluation of the waterless toilet as an alternative to the failing soil absorption system. In: Individual onsite wastewater systems — proceedings of the NSF eighth national conference 1981: 201-209

Epstein E (1997) The Science of Composting. Technomic Publishing Company Inc., Lancaster, p 487

Feachem RG, Bradley DJ, Garelick H, Mara DD (1983) Sanitation and disease. Health aspects of excreta and wastewater management. World bank studies in water supply and sanitation. John Willey and Sons, New York

Fittschen I, Niemczynowicz J (1997) Experiences with dry sanitation and greywater treatment in the ecovillage Toarp, Sweden. Water Sci Technol 35:161-170

Flynn RP, Wood CW (1996) Temperature and chemical changes during composting of broiler litter. Compost Science \& Utilization 4(3):62- 70 Franceys R (1992) A guide to the development of on-site sanitation.WHO, Geneva

Gajalakshmi S, Abbasi SA (2008) Solid waste management by composting: state of the art. Crit Rev Environ Sci Technol $38: 311-400$

Germer J, Boh MY, Schoeffler M, Amoah P (2010) Temperature and deactivation of microbial faecal indicators during small scale cocomposting of faecal matter. Waste Manag 30:185-191

Grewal SK, Rajeev S, Sreevatsan S, Fredrick CM (2006) Persistence of Mycobacterium avium subsp. paratuberculosis and other zoonotic pathogens during simulated composting, manure packing, and liquid storage of dairy manure. Appl Environ Microbiol 72:565-574

Haug RT, Haug HT (1993) The practical handbook of compost engineering. Boca Raton, Lewis publishers, CRC Press Inc

Heinrich D, Hergt M (1993) Atlas de l'écologie. LGF, Livre de Poche, Paris

Hill GB, Susan AB (2012) Vermicomposting toilets, an alternative to latrine style microbial composting toilets, prove far superior in mass reduction, pathogen destruction, compost quality, and operational cost. Waste Manag 32(10):1811-1820

Holmqvist A, Stenstrom AT (2002) Survival of Ascaris suum ova, indicator bacterial and salmonella typhimurium phage 28B in mesophilic composting of household waste. EcoSanRes, Stolkholm Environment Institute, Sweden Hsu JH, Lo SL (1999) 
Recycling of separated pig manure: characterization of maturity and chemical fractionation of elements during composting. Water Sci Technol 40(1):121-127

Huang RT (1993) The practical handbook of compost engineering. Lewis Publishers, Boca Raton, ISBN 0-87371, pp 373-377

Iglesias Jiménez E, Pérez Garcia V (1991) Composting of domestic refuse and sewage sludge. I. Evolution of temperature, pH, $\mathrm{C} / \mathrm{N}$ ratio, and cation exchange capacity. Resour Conserv Recycl 6(1):45-60

Inbar Y, Hadar Y, Chen Y (1993) Recycling of cattle manure: the composting process and characterization of maturity. J Environ Qual 22(4):857-863

Jenkins J (1999) The humanure handbook: a guide to composting human manure, 2nd edn. Jenkins Publishing, Grove City, p 154

Jenkins J (2005) The humanure handbook. Chelsea Green Publishing, White River Junciton

Jensen PKM, Phuc PD, Konradsen F (2009) Survival of Ascaris eggs and hygienic quality of human excreta in Vietnamese composting latrines. Environ Health 8:57

Kaczala F (2006) A review of dry toilet systems. Department of Technology, University of Kalmar, Linnaeus

Ko HJ, Kim KY, Kim HT, Kim CN, Umeda M (2008) Evaluation of maturity parameters and heavy metal contents in composts made from animal manure. Waste Management 28:813-820

Lasaridi KE, Stentiford EI, Evans T (2000) Windrow composting of wastewater biosolids: process performance and product stability assessment. Water Sci Technol 42(9):217-226

Leich HH (1981) Norwegians test 21 composting toilets. Biocycle 22(2):22-23

Li HF, Imai T, Ukita M, Sekine M, Higuchi T (2004) Compost stability assessment using a secondary metabolite: geosmin. Environ Technol 25(11):1305-1312

Mathur SP, Owen G, Dinel H, Schnitzer M (1993) Determination of compost biomaturity. I. Literature review. Biol Agric Hortic 10: 65-85Miller FC (1992) Composting as a process based on the control of ecologically selective factors. In: Metting

FB Jr (ed) Soil microbial ecology, applications in agricultural and environmental management. Marcel Dekker Inc., New York, pp 515-544

Nataka S, Zavala MAL, Funamizu N, Otaki M, Takakuwa T (2003) Temperature effect on pathogens decline in the bio-toilet system. In: Proceedings of the 1st International Dry Toilet Conference: Dry Toilet. Tampere, Finland

NFU 44-095 (2004) Amendements organiques - Composts contenant des matières d'intérêt agronomique, issues du traitement des eaux. French national standard collection. composting of the sludge form wastewater plants, Paris

Paterson C, Mara D, Curtis T (2007) Pro-poor sanitation technologies. Geoforum 38(5):901-907

Prüss-Ustün A, Bartram J, Clasen T, Colford JM, Cumming O, Curtis V, Bonjour S, Dangour AD, De France J, Fewtrell L (2014) Burden of disease from inadequate water, sanitation and hygiene in low-and middle-income settings: a retrospective analysis of data from 145 countries. Tropical Med Int Health 19(8):894-905

Pujari PR, Nanoti M, Nitnaware VC, Khare LA, Thacker N, Kelkar P (2007) Effect of on-site sanitation on groundwater contamination in basaltic environment case study from India. Environ Monit Assess 134(1):271

Rapaport D (1996) The CCD toilet. An aerobic double vault composting toilet for tropical environments that achieves zerodischarge sanitation with low maintenance requirements. Center for Clean Development, Oregon

Redlinger T, Graham J, Corella-Barud V (2001) Survival of fecal coliforms in dry-composting toilets. Appl Environ Microbiol 67:4036-4040

Rubin AR, Claude P, Jerry S (2012) On-site wastewater treatment systems. Washington State Department of Health, Recommended Standards and Guidance for Performance, Application, Design, \& Operation Maintenance. DOH Publication, Washington

Savage AJ, Tyrrel SF (2004) Compost liquor bioremediation using waste materials as bio filtration media. Bioresour Technol 96(5):557-564

Smith ME (1981) Evaluation of compost toilets. United States Department of Agriculture, Equipment Development Centre, San Dimas 
Smith ED, Poon CP, Struss SR, Bandy JT, Scholze RJ (1984) Appropriate technology for treating wastewater at remote sites on army installations: preliminary findings. Construction Engineering Research Laboratory, Champain (Technical report: N160)

Stoner CH (1977) Goodbye to the flush toilet: water-saving alternatives to cesspools, septic tanks, and sewers. Rodale Press, Emmaus

Strande L, Mariska R, Damir B (2014) Faecal sludge management: systems approach for implementation and operation. IWA Publ,London

Templeton MR, Hammoud AS, Butler AP, Braun L, Foucher JA, Grossmann J, Boukari M, Faye S, Jourda JP (2015) Nitrate pollution of groundwater by pit latrines in developing countries. AIMS Environ Sci 2(2):302-313

Tønner-Klank L (2007) Microbiological assessments of compost toilets: in situ measurements and laboratory studies on the survival of fecal microbial indicators using sentinel chambers. Waste Manag (New York, NY) 27:1144-1154

Vinneras B, Bjorklund A, Jonsson H (2003) Thermal composting of faecal matter as treatment and possible disinfection methodlaboratory-scale and pilot-scale studies. Bioresour Technol 88:47-54

Weppen P (2001) Process calorimetry on composting of municipal organic wastes. Biomass Bioenergy 21:289-299

Weissenbacher N, Mayr E, Niederberger T, Aschauer C, Lebersorger S (2008) Alpine infrastructure in Central Europe: integral evaluation of wastewater treatment systems at mountain refuges. Water Sci Technol 57(12):2017-2022

WHO/UNICEF (2014) Progress on drinking water and sanitation: 2014 update. Tech. rep. WHO/UNICEF Joint Monitoring Programme for Water Supply and Sanitation, Luxembourg

Wichuk KM, McCartney D (2010) Compost stability and maturity evaluation—a Literature review. J Environ Eng Sci 37(11):5

Winblad U, Mayling SH, Calvert P (2004) Ecological sanitation. Stockholm Environment Institute, Stockholm

Withers PJA, May HP, Jarvie P, Jordan D, Doody RH, Foy M, Bechmann S, Cooksley R, Dils N, Deal N (2012) Nutrient emissions to water from septic tank systems in rural catchments: uncertainties and implications for policy. Environ Sci Pol 24:71-82

Wu L, Ma LQ, Martinez GA (2000) Comparison of methods for evaluating stability and maturity of biosolids compost. J Environ Qual 29(2):424-429

Young B (1986) A background report on Clivus Multrum composting toilets at Kosciusko National Park. National Parks and Wildlife Service, New South Wales

Zavala MAL, Funamizu N (2006) Design and operation of the bio-toilet system. Water Sci Technol 53:55-61

Zavala MAL, Funamizu N, Takakuwa T (2004) Temperature effect on aerobic biodegradation of faeces using sawdust as a matrix. Water Res 38(9):2406-2416 